\title{
A new concept: the use of protective hydrogel in maxillofacial surgery - case report
}

\section{Nowa koncepcja: zastosowanie ochronnego hydrożelu w chirurgii szczękowo-twarzowej. Opis przypadku}

\author{
Ricardo Grillo ${ }^{1}$, Gabriel Pedrosa ${ }^{2}$, Rubens Gonçalves Teixeira ${ }^{1}$ \\ ${ }^{1}$ Department of Oral Surgery, Institute and Research Centre, São Leopoldo Mandic, Brazil \\ 2 Maxillofacial surgery, private practice, Brazil
}

KEY WORDS:

Fracture Fixation, hydrogels, Focal Infection, biofilms

\section{Summary}

Infections in oral and maxillofacial surgery are a very common complication, about $11 \%$ of all surgical procedures in Brazil. There are some steps to prevent and treat oral and maxillofacial surgery infections. In this paper, we introduce a new material to deal with these complications. Protective DAC hydrogel is made of hyaluronic acid and poly-L-lactic acid plus antibiotic and antibiofilm agents. This hydrogel is useful where implants are installed like prosthesis or stable internal fixation, mainly in cases when a second surgical step is needed, because of an infection, mainly in cases of biofilm infection over internal fixation plates and/or screws. A case is reported here to exemplify one of the utilities of this new product. The use of protective hydrogel is very useful in oral and maxillofacial surgery, not only for prevention but also in cases of replacement of infected implants due to biofilm or any other source of infection.
HASŁA INDEKSOWE:

stabilizacja złamania, hydrożele, ogniskowa infekcja, biofilmy

\section{Streszczenie}

Infekcje $w$ chirurgii jamy ustnej i szczekowo-twarzowej sa bardzo częstym powikłaniem, stanowiacym około $11 \%$ wszystkich zabiegów chirurgicznych w Brazylii. Istnieje kilka kroków $w$ celu zapobiegania i leczenia infekcji jamy ustnej $i$ szczękowo-twarzowej. Przedstawiany w tym artykule nowy materiat jest skuteczny $w$ tych komplikacjach. Hydrożel ochronny DAC zawiera kwas hialuronowy i poli-L-mlekowy oraz antybiotyki $i$ antybiofilm. Hydrożel jest wskazany, gdy implanty zaktadane sa jako samodzielne uzupetnienie lub stanowia stabilne mocowanie, szczególnie w przypadku konieczności drugiego etapu chirurgicznego z powodu infekcji głównie $z$ powodu biofilmu na wewnętrznych plytkach mocujacych i/lub śrubach. Opisywany przypadek ilustruje jedno z zastosowań tego produktu. Wdrożenie hydrożelu ochronnego do chirurgii jamy ustnej $i$ szczękowo-twarzowej, nie tylko znajduje zastosowanie $w$ profilaktyce, ale także $w$ przypadkach wymiany implantów z powodu zakażenia wywołanego wystepowaniem biofilmu lub innymi czynnikami. 


\begin{abstract}
Infections in oral and maxillofacial surgery are a very common complication, about $11 \%$ of all surgical procedures in Brazil. There are some steps to prevent and treat oral and maxillofacial surgery infections. In this paper, we introduce a new material to deal with these complications. Protective DAC hydrogel is made of hyaluronic acid and poly-L-lactic acid plus antibiotic and antibiofilm agents. This hydrogel is useful where implants are installed like prosthesis or stable internal fixation, mainly in cases when a second surgical step is needed, because of an infection, mainly in cases of biofilm infection over internal fixation plates and/or screws. A case is reported here to exemplify one of the utilities of this new product. The use of protective hydrogel is very useful in oral and maxillofacial surgery, not only for prevention but also in cases of replacement of infected implants due to biofilm or any other source of infection.
\end{abstract}

\section{Introduction}

Surgical site infections in Brazil affect about $15 \%$ of hospitalized patients, occupying the third position in all cases in health services. ${ }^{1}$ It is a common complication, concerning about $11 \%$ of surgical procedures.

There is a classification of degrees of risk of greater potential for infection of the surgical site: opening of hollow or mucous window; procedure with a longer duration; size of the surgery and insertion of prosthesis. In some oral and maxillofacial surgeries more than one of these elements is present, as in cases of TMJ prostheses or orthognathic surgeries.

Many maneuvers and steps are taken in order to decrease the odds, not only in the surgical site, but also in other sites. Among them, we can mention: antibiotic prophylaxis, decreasing postoperative hospital stay, antisepsis of the operative field and maintenance of the aseptic chain during surgery, among others.

One, relatively new, aim to reduce, or even exclude the occurrences of infection in the surgical site, is the use of protective hydrogel impregnated with antibiotics under the surfaces of prostheses and other implants. This hydrogel is composed of hyaluronic acid and poly-lactic acid, ${ }^{2}$ two extremely safe materials, impregnated with a selection of antibiotics (vancomycin, gentamicin, tobramycin, ciprofloxacin, meropenem, amikacin, clindamycin, doxycycline $)^{3,4}$ and antibiofilm compounds. This hydrogel has the capacity to release antibiotics and antibiofilm compounds for a period of up to 96 hours, ${ }^{2,3}$ with a peak in the first two hours, generating greater protection for the surgical site. ${ }^{2,4}$

It is one more alternative in the arsenal of the maxillofacial surgeon for the prophylaxis and treatment of surgical site infections caused by biofilm.

\section{Case report}

A 32-year-old female patient underwent bimaxillary orthognathic surgery. The patient was admittedfor maxillomandibular advancement of $3 \mathrm{~mm}$ for correction of bimaxillary retrusion, and a $4 \mathrm{~mm}$ advancement mentoplasty was also performed to achieve a better aesthetics and respiratory improvement. The surgery proceeded without any complications, without excessive bleeding and with a duration of less than 4 hours. The patient was discharged on the next day. All infection prevention measures were taken, using antibiotic prophylaxis and maintenance of the aseptic chain.

The patient had no complaint and started physiotherapy to return to function, twentyeight days after surgery. The professional, in an untimely and sudden maneuver, moved the mandibular stumps with excessive force, which caused the displacement of the 


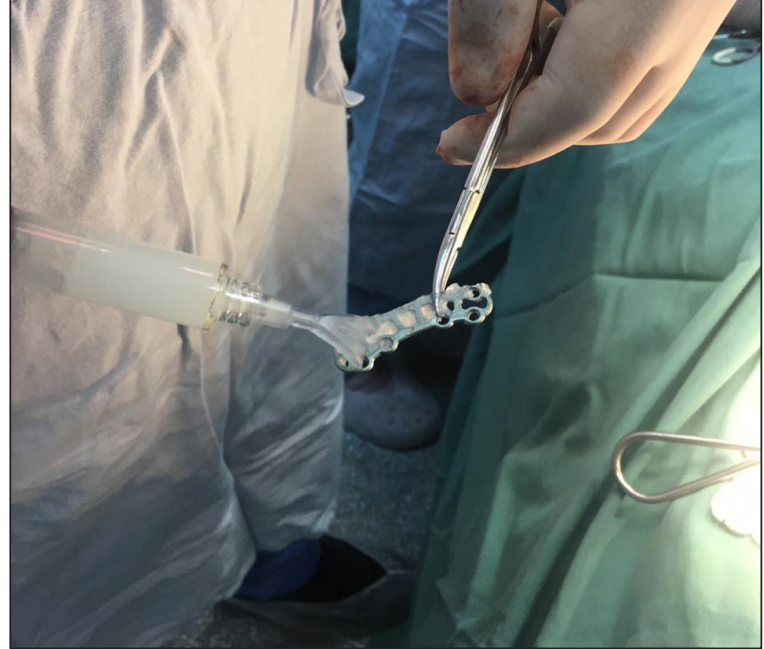

Fig. 1. Plate being impregnated with DAC hydrogel.

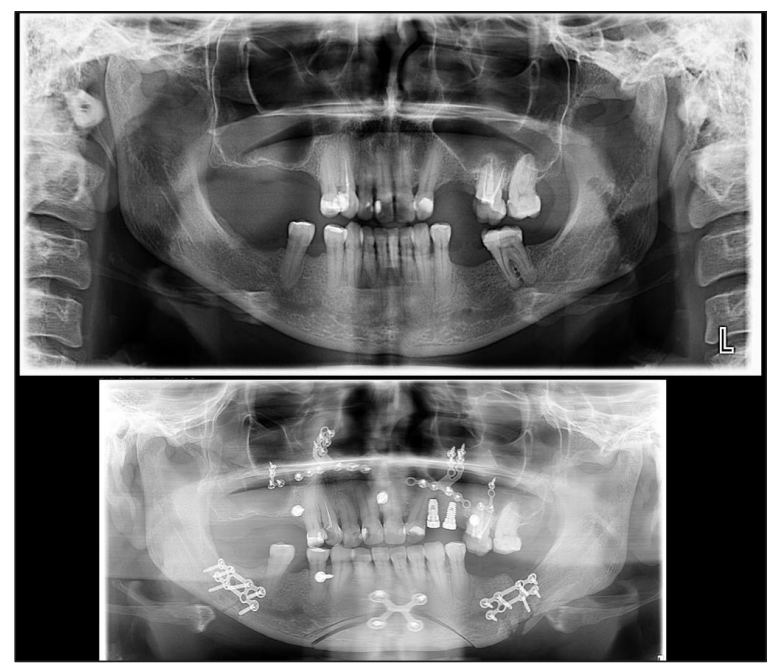

Fig. 2. Before and after orthognathic surgery panoramic radiographies. synthesis material. In less than a week, the patient began to show signs and symptoms of infection in the region, such as pain, oedema, limited mouth opening and the presence of a purulent collection with exposure of the synthesis material.

Due to the short time in which this situation had occurred, it was decided not only to remove the now exposed synthesis material and loose screws, but also to replace it due to the great risk of pseudoarthrosis.

The synthesis material of the previous orthognathic surgery was completely removed. The region received copious irrigation of saline solution in addition to curettage at some specific points in order to remove small bone fragments and other foreign bodies resulting from trauma and the removal of osteosynthesis.

During the replacement of the synthesis material, the use of the DAC protective hydrogel was opted for in order to impregnate the titanium with antibiotics and antibiofilm compounds, decreasing the chance of infection at the surgical site. The protective hydrogel DAC ${ }^{\circledR}$ (Defensive Antibacterial Coating; Novagenit Srl, Mezzolombardo, Italy) is not ready for use. It needs to be hydrated with water the moment it is used so that the release property of the compounds is maintained for a longer time, in addition to preventing oxidation of the components, decreasing their effectiveness. This procedure was performed according to the manufacturer's guidelines.

After impregnating the synthesis materials and installing all the plates and screws, the region was sutured and all precautions related to surgeries of this size were taken, such as appropriate medication, ice packs, elevated bed position, among others (Fig. 1).

After threemonths, the patient was in excellent health, without any evidence of infection or any other complication that would result in the loss of the result obtained with orthognathic surgery such as malocclusion, midline deviation and functional complaints such as masticatory, respiratory or aesthetic deficits. The patient did not report any level of paresthesia. It is the belief of the authors of this study that this is the first report of the use of DAC protective hydrogel in oral and maxillofacial surgery in the American continent.

The patient had been informed about the new procedure and consented to any surgical or clinical procedure involving DAC hydrogel. 
This procedure was done in a private practice. All procedures here listed followed the Helsinki Declaration protocols (Fig. 2).

\section{Discussion}

Infections are one of the most common and severe complications in surgeries where implants have been used, whether as stable internal fixation material ${ }^{5}$ or a prosthesis. . $^{2,5,7}$ The formation of biofilm on the surface of the implants is difficult to treat mainly because the bacteria of this type of infection are protected both from phagocytosis and from the action of antibiotics. ${ }^{2}$ Staphylococci are the most common microorganisms in this type of infection, more specifically methicillin-resistant Staphylococci aureus ${ }^{8}$ and Staphylococci epidermidis. ${ }^{9}$

Different techniques and materials have been used for a long time in order to prevent the formation of biofilms, but some obstacles have not been overcome, such as the local release of antibiotics for a longer period of time, costs, systemic risks, regulatory problems or even alteration of the bone neoformation pattern. $2,9,10$

The protective hydrogel has been used for some years with great success, mainly in the use of joint prostheses. ${ }^{5}$ Hydrogels and the possibility of adapting them to the characteristics of each surgery make it a great candidate for a carrier agent. ${ }^{4}$ It can be used in combination with antibiotics, antibiofilm agents and other substances, without altering the characteristics and functions of these substances. The hydration procedure is fast and involves few steps. ${ }^{7}$ The gel has high viscosity (150-400Pa), which makes it extremely adhesive to the surface of the implanted materials. ${ }^{8}$ The kits for reconstitution are for single use and cannot be reused in other patients. ${ }^{7}$ The sterilization of the hydrogel does not change its rheological behaviour, or the release properties of substances as well as the structure of its polymers.

It has the function of covering the implant, increasing the surface energy of the material, which promotes bone growth and generates stem cell differentiation in osteoblasts, without interfering with bone-implant stability ${ }^{4,10}$ and increasing osseointegration. In addition to this function, some antimicrobials can be added to the hydrogel in its composition, which reduces bacterial adhesion, dramatically decreasing the chances of postoperative infections due to the presence of biofilm. ${ }^{3,5}$ This bactericidal action can last up to 96 hours, 7 reducing the bacterial load in almost all cases. ${ }^{3,7,8}$ The initial concentration of $20 \mathrm{mg} / \mathrm{ml}$ generates, after 96 hours, a concentration of about 200 to $300 \mu \mathrm{g} / \mathrm{ml}^{7}$ An important detail is that the hydrogel does not interfere with the mechanical stability of the implants. ${ }^{4}$

The protective hydrogel becomes superior to the local application of high concentrations of antibiotics as a prophylaxis or treatment of infections because these high concentrations can be toxic to osteoblasts affecting bone growth. ${ }^{4}$ There is no difference between the amount of bone per apposition, in the time of bone apposition and in the histopathology of the inflammatory response between the group that was submitted to the use of the protective hydrogel and the control group. 4,8

Of all the antibiotics possible to be used with the protective hydrogel, vancomycin and gentamicin were used most, as they have chemical properties superior to other antibiotics when in contact with hydrogel. ${ }^{2}$ It did not affect either the time or the amount of bone apposition, nor did it induce an inflammatory response around the implants or cause a systemic inflammatory reaction, which confirms its histocompatibility. $4,7,8$ Only morphological changes were observed, including moderate periosteal reaction and minimal enlargement of the Harvesian 
channels, but these changes cannot be attributed to the hydrogel itself since they were also found in the group where only implants were installed. ${ }^{4}$ Even though the formulation is ready to use following hydration, there is the possibility of adding other substances to the hydrogel, such as other antibiotics and other biofilm agents. ${ }^{8}$

The antibiofilm agent mostly used in the protective gel is NAC (N-acetylcysteine) for its safety in parenteral use and for its antibacterial effect, but it is still not widely studied for use in orthopaedics or oral and maxillofacial surgery. ${ }^{2}$

The authors made a reference research in MEDLINE and LILACS. There are no papers regarding DAC hydrogel AND oral surgery AND/OR maxillofacial surgery found in bibliographic research. This is the first publication regarding DAC hydrogel and oral/ maxillofacial surgery.

The protective hydrogel is a safe material, without side effects and effective in the prophylaxis and/or treatment of infections arising from biofilm which adheres to the implant surfaces $5,9,10$ being an efficient covering material for these implants.

\section{Conclusion}

The DAC protective hydrogel is a valuable option in protecting implants from bacterial colonization. To date, there is no evidence of poor bone neoformation with the use of the gel, which makes it a safe material. DAC is a useful alternative in cases of post orthognathic surgery infections without the need of osteosynthesis removal, as reported.

Studies with this material have been performed on a small sample, even with animals, and, although promising, they still need more research to detect any late complication and confirm its effectiveness in vivo.

\section{References}

1. Agência Nacional de Vigilância Sanitária (Anvisa). SÍTIO CIRÚRGICO Critérios Nacionais de Infecções relacionadas à assistência à saúde 2009.

2. Drago L, Boot $W$, Dimas $K$, Malizos $K$, Hänsch GM, Stuyck J, Gawlitta D, Romanò $C L$ : Does implant coating with antibacterialloaded hydrogel reduce bacterial colonization and biofilm formation in vitro? Clin Orthop Relat Res 2014; 472(11): 3311-3323.

3. Meani E, Fini M, Giavaresi G, Drago L, Romano $C L$ : Antibacterial resorbable coating of orthopaedic implants: na in vitro and in vivo study. Bone Joint J 2014; 96B (11): 284.

4. Boot W, Gawlitta D, Nikkels PGJ, Pouran $B$, van Rijen MHP, Dhert WJA, Vogely HCh: Hyaluronic Acid-Based Hydrogel Coating Does Not Affect Bone Apposition at the Implant Surface in a Rabbit Model. Clin Orthop Relat Res 2017; 475(7): 1911-1919.

5. Malizos K, Blauth M, Danita A, Capuano N, Mezzoprete R, Logoluso N, Drago L, Romanò $C L$ : Fast-resorbable antibiotic-loaded hydrogel coating to reduce post-surgical infection after internal osteosynthesis: a multicenter randomized controlled trial. J Orthop Traumatol 2017; 18(2): 159-169.

6. Zhang BG, Myers DE, Wallace GG, Brandt $M$, Choong $P F$ : Bioactive coatings for orthopaedic implants-recent trends in development of implant coatings. Int $\mathrm{J}$ Mol Sci 2014; 15(7): 11878-11921.

7. Romanó CL, Drago L, Giavaresi G, Sambri $V$, Fini M, Boot $W$, Hänsch GM, Meani E: Prevenzione dele infezioni peri-protesiche mediante revestimento riassorbibile antibatterico: um nuovo approccio? Lo Scalpello 2013; 27: 88-94.

8. Giavaresi $G$, Meani E, Sartori M, Ferrari A, Bellini D, Sacchetta AC, Meraner J, Sambri A, Vocale C, Sambri V, Fini M, Romanò CL: Efficacy of antibacterial-loaded coating in an 
in vivo model of acutely highly contaminated implant. Int Orthop 2014; 38(7): 1505-1512.

9. Lovati AB, Drago L, Bottagisio M, Bongio $M$, Ferrario $M$, Perego $S$, Sansoni $V$, De Vecchi E, Romanò CL: Systemic and Local Administration of Antimicrobial and Cell Therapies to Prevent Methicillin-Resistant Staphylococcus epidermidis-Induced Femoral Nonunions in a Rat Model. Mediators Inflamm 2016; 2016: 9595706.

10. Malizos K, Scarponi S, Simon K, Blauth M,
Romanó C: Clinical results of na anti-bacterial hydrogel coating of implants: a multicentre, prospective, comparative study. Bone Joint $\mathrm{J}$ 2015; 97B (16): 138.

Zaakceptowano do druku: 7.12.2020 r.

Adres autorów: prof. Ricardo Grillo,

Department of Oral Surgery, Institute and Research Centre, São Leopoldo Mandic 13045-755 Campinas, SP, Brazil.

C) Zarząd Główny PTS 2020. 